\title{
Tingkat Tutur Pengisi Fungsi Subjek Bahasa Korea dan Bahasa Jawa
}

\author{
Subject Honorific in Korean dan Javanese \\ Iva Hanani ${ }^{1}$, Suray Agung Nugroho \\ Universitas Gadjah Mada ${ }^{1}$ \\ hananiiva@gmail.com ${ }^{1}$ \\ Universitas Gadjah Mada ${ }^{2}$ \\ suray@ugm.ac.id ${ }^{2}$
}

\begin{abstract}
The aim of this study is to explain Korean and Javanese subject honorific and identify its similarities and differences. To accomplish it, this research was conducted using literature review method. Data related to the Javanese language were taken from two Javanese drama scripts, namely Mak Ana Asu Mlebu Ngomah and Bantul Sangsaya Pinunjul, and Javanese drama titled Sri Ngilang by George Quinn. Korean language data was taken from television drama, Misaeng and Fight for My Way. Based on the analysis that has been carried out, despite the difference of the honorific system of Korean dan Javanese, Javanese has subject honorific as described in the Korean honorific system. Both languages use words that have honorific meaning to honor the subject and use words that are usually used for the animal to dishonor the subject of the sentence. The difference between both languages on subject honorific is Korean subject honorific is mainly realized grammatically, whereas in Javanese is realized lexically. In addition, there are rules from the Korean government regarding the use of one type of subject honorific, abjonbeob, whereas in Javanese there are no rules related to the use of speech level.
\end{abstract}

Keywords: honorific system, Javanese, Korean, subject honorific

\section{INTISARI}

Penelitian ini bertujuan untuk mengetahui sistem tingkat tutur pengisi fungsi subjek bahasa Korea dan bahasa Jawa serta mengetahui persamaan dan perbedaan dari tingkat tutur untuk fungsi subjek di kedua bahasa tersebut. Penelitian ini dilakukan dengan metode studi literatur. Sumber data penelitian yang terkait bahasa Jawa diambil dari dua kumpulan naskah drama bahasa Jawa, yaitu Mak Ana Asu Mlebu Ngomah dan Bantul Sangsaya Pinunjul, dan drama bahasa Jawa berjudul Sri Ngilang garapan George Quinn. Untuk sumber data bahasa Korea diambil dari drama Misaeng dan Fight for My Way. Dari analisis yang telah dilakukan, dapat disimpulkan bahwa meskipun sistem tingkat tutur bahasa Jawa dan bahasa Korea berbeda, bahasa Jawa memiliki tingkat tutur untuk fungsi subjek seperti bahasa Korea. Tingkat tutur untuk fungsi subjek bahasa Korea sebagian besar terwujid secara gramatikal, sedangkan dalam bahasa Jawa terwujud secara leksikal. Selain itu, dalam bahasa Korea ada ketentuan dari pemerintah Korea melalui Etika Berbahasa Korea Standar atau pyojun eoneo yejeol terkait penggunaan apjonbeob, sedangkan di bahasa Jawa tidak ada.

Kata kunci: bahasa Jawa, bahasa Korea, fungsi subjek, tingkat tutur

Panduan sitasi:

Hanani, I., Nugroho, S. A. (2020). Tingkat Tutur Pengisi Fungsi Subjek Bahasa Korea dan Bahasa Jawa. JLA

(Jurnal Lingua Applicata), 3(2), 71-86 


\section{PENDAHULUAN}

Ada beberapa hal yang perlu diperhatikan pada saat berkomunikasi dengan orang lain, salah satunya adalah kesopanan. Brown dan Levinson (1996) mengatakan bahwa kesopanan pada saat berkomunikasi dapat ditunjukkan melalui beberapa hal, salah satunya adalah dengan menghormati lawan bicara. Penghormatan kepada lawan bicara dapat ditunjukkan melalui sikap dan bahasa. Untuk menghormati lawan bicara melalui bahasa dapat dilakukan melalui penggunaan tingkat tutur.

Beberapa bahasa di dunia mengenal tingkat tutur. Ada beberapa bahasa yang sistem tingkat tuturnya terbilang rumit dan ada yang tidak. Bahasa yang tingkat tuturnya termasuk berkembang dan dikenal rumit, beberapa diantaranya adalah bahasa Korea dan bahasa Jawa. Dikarenakan rumpun bahasa yang berbeda dan beberapa latar belakang lainnya, tentunya sistem tingkat tutur kedua bahasa ini berbeda.

Tingkat tutur bahasa Korea dibagi berdasarkan objeknya, yaitu tingkat tutur pengisi fungsi subjek, tingkat tutur pengisi fungsi objek dalam kalimat dan tingkat tutur lawan bicara (Kim, 2016). Bahasa Jawa membagi tingkat tutur berdasarkan kadar kesopanan pembicara terhadap mitra tutur. Tingkat tutur ini dibagi menjadi ngoko, madya dan krama (Poedjasoedarma, 1979).

Terkait dengan penelitian tentang perbandingan tingkat tutur bahasa Korea dan bahasa Jawa secara umum, di Indonesia belum ada. Akan tetapi, ada satu penelitian di Korea yang membandingkan tingkat tutur bahasa Korea dan bahasa Jawa. Penelitian tersebut dilakukan oleh Rahayuning (2018) yang membahas tentang tingkat tutur dalam bahasa Korea dan bahasa Jawa yang berfokus pada tingkat tutur lawan bicara (상대높임법) dalam bahasa Korea dan bahasa Jawa. Dalam penelitian tersebut dijelaskan tentang sistem tingkat tutur lawan bicara di masing-masing bahasa. Kemudian, dibandingkan pula perbedaan dan persamaan di kedua bahasa. Hasil penelitian tersebut menyimpulkan bahwa tingkat tutur lawan bicara bahasa Korea ini mirip dengan sistem tingkat tutur bahasa Jawa secara keseluruhan.

Penelitian sebelumnya telah membuktikan bahwa meskipun sistem tingkat tutur bahasa Korea dan bahasa Jawa berbeda, tetapi ada kesamaan, yaitu pada tingkat tutur lawan bicara. Artikel ini akan membahas mengenai dua hal, yaitu: 1) bagaimana tingkat tutur pengisi fungsi subjek bahasa Korea dan bahasa Jawa? dan 2) apa saja perbedaan dan persamaan dari keduanya?

\section{METODE PENELITIAN}

Penelitian ini dilakukan dengan menggunakan studi literatur. Sumber data bahasa Korea diambil dari drama Misaeng yang tayang pada tahun 2014 dan Fight for My Way yang tayang pada tahun 2017. Data yang berkaitan dengan bahasa Jawa diambil dari kumpulan naskah drama bahasa Jawa Mak Ana Asu Mlebu Ngomah (Wahyudi, 2014), Bantul Sangsaya Pinunjul (Abidan, 2011) dan drama bahasa 
Jawa berjudul Sri Ngilang garapan George Quinn yang diakses melalui kanal Youtube Digital Learning Project milik Australian National University.

\section{HASIL DAN PEMBAHASAN}

\section{1) Tingkat Tutur Bahasa Korea}

Tingkat tutur dalam bahasa Korea disebut dengan berbagai istilah, diantaranya adalah gyeongeobeob (경어법), jondaebeob (존대법), daewoobeob (대우법) dan nophimbeob (높임법). Di antara semua istilah tersebut, istilah yang lebih umum dipakai adalah nophimbeob. Kata nophimbeob berasal dari kata nophim yang berarti meninggikan dan beob yang berarti sistem atau cara (Lee, 2001). Han (2002) menyebutkan bahwa nophimbeob atau tingkat tutur adalah penggunaan tuturan yang benar sesuai dengan situasi, tingkat keakraban dan hubungan hierarki pembicara dengan objek. Selain itu, fungsi utama tingkat tutur tidak hanya berhubungan dengan meninggikan lawan bicara, tetapi juga termasuk merendahkan lawan bicara.

Kim (2016) mengungkapkan bahwa sama halnya dengan kata 'panjang' yang di dalamnya memuat 'panjang dan pendek' dan kata 'luas' yang di dalamnya masuk 'luas dan sempit', kata nophim yang berarti meninggikan pun di dalamnya memuat 'nophim dan najchum' yang artinya 'meninggikan dan merendahkan'1'. Maka

\footnotetext{
${ }^{1}$ Kata 'merendahkan' dalam konteks ini mencakup merendahkan (hina) orang lain dan tidak
}

dari itu, nophimbeob atau tingkat tutur merupakan kategori gramatikal yang tidak hanya untuk meninggikan, tetapi juga merendahkan lawan bicara atau objek yang muncul sebagai subjek atau objek dalam kalimat.

Secara umum, terdapat tiga macam tingkat tutur dalam bahasa Korea berdasarkan objeknya. Tingkat tutur tersebut adalah tingkat tutur lawan bicara atau cheongjanophimbeob (청자높임법), tingkat tutur pengisi fungsi objek atau gaekchenophimbeob (객체높임법), dan tingkat tutur pengisi fungsi subjek atau juchenophimbeob (주체높임법). Pada setiap jenis tingkat tutur tersebut, Kim (2016) membaginya lagi menjadi dua, yaitu tinggi dan rendah.

Tingkat tutur lawan bicara adalah tingkat tutur yang meninggikan atau merendahkan pendengar. Tingkat tutur ini ditandai dengan penggunaan final ending dan vocative particle pada setiap tingkatannya dan masing-masing menunjukkan tingkat kesopanan yang berbeda-beda. Seperti yang sudah disebutkan di atas, tingkat tutur ini dibagi menjadi dua, yaitu tinggi dan rendah. Tingkat tutur lawan bicara yang dikategorikan tinggi ada tiga dan sesuai tingkat kesopanannya adalah ajunophim (아주 높임), yesanophim (예사 높임), durunophim (두루높임). Masingmasing dari tingkat tutur tersebut memiliki final endingnya masing-masing, yaitu eusipsio (으십시오)/bnida (브니다/습니다), -oh/ -so/-guryeo (-오/-소/-구려), dan -a/eoyo

meninggikan atau mengenai honorifik pada orang lain. 
(-아/어요). Tingkat tutur lawan bicara yang dikategorikan rendah ada tiga, yaitu yesanajchum (예사 낮춤), ajunajchum (아주 낮춤), dan durunajchum (두루낮춤). Masing-masing memiliki final ending -se (-세), -a/eora (-아/어라) dan -a/eo (-아/어) (Kim, 2016).

Tingkat tutur pengisi fungsi objek adalah tingkat tutur yang digunakan untuk meninggikan atau merendahkan orang yang mengisi fungsi objek atau dative $\operatorname{case}^{2}$ dalam kalimat. Tingkat tutur ini pun juga dibagi menjadi dua, yaitu tinggi dan rendah. Tingkat tutur yang tinggi ditandai dengan penggunaan dative marker ${ }^{3}-k k e$ (-ᄁᄁ) pada pengisi fungsi dative case. Dative marker tersebut digunakan bersamaan dengan kata kerja deurida (드리다) dan $b a$ chida (바치다) yang keduanya berarti memberi. Selain itu, juga digunakan kata moshida yang berarti mengajak atau membawa seseorang dan bwebta (뵙다) yang berarti bertemu dan digunakan untuk objek langsung. Tingkat tutur yang dikategorikan rendah pada umumnya menggunakan kata yang tidak memiliki makna honorifik.

Tingkat tutur pengisi fungsi subjek adalah tingkat tutur yang digunakan untuk meninggikan atau merendahkan orang yang menempati fungsi subjek dalam kalimat. Tingkat tutur ini pun dibagi menjadi tinggi dan rendah pada setiap jenisnya. Je-

\footnotetext{
${ }^{2}$ Dative case adalah unsur gramatikal di beberapa bahasa yang mengindikasikan penerima sebuah tindakan.

${ }^{3}$ Dative marker merupakan penanda gramatikal yang mengindikasikan penerima suatu tindakan.
}

nis tingkat tutur untuk fungsi subjek ada empat, yaitu langsung atau jikjob nophim (직접 높임), tidak langsung atau ganjeobnophim (간접 높임), abjonbeob (압존법) dan gajonbeob (가존법) (Kim, 2016). Ketika pengisi fungsi subjek adalah orang, maka disebut tingkat tutur pengisi subjek langsung. Tingkat tutur pengisi subjek langsung ini terwujud secara gramatikal, yaitu dengan adanya penanda subjek -kkeseo dan pre-final ending -si-pada predikat. Namun, penanda gramatikal ini hanya digunakan ketika meninggikan orang yang mengisi fungsi subjek.

Sama halnya dengan tingkat tutur pengisi fungsi subjek langsung, tingkat tutur pengisi fungsi subjek tidak langsung juga menggunakan pre-final ending -sipada predikatnya. Akan tetapi yang berbeda adalah pengisi fungsi subjeknya bukan orang, tetapi barang, kepunyaan atau hal-hal lain yang berkaitan dengan objek yang dikenai honorifik. Dalam kasus ini, yang ditinggikan bukanlah benda tersebut, tetapi pemilik benda tersebut. Jadi, dengan kata lain, meninggikan orang lain melalui benda atau kepunyaan yang dimilikinya.

Apjonbeob dan gajonbeob merupakan tingkat tutur pengisi fungsi subjek yang ditentukan melalui hubungan antara pembicara, lawan bicara dan orang yang mengisi fungsi subjek. Apjonbeob adalah tidak meninggikan pengisi fungsi subjek yang seharusnya ditinggikan karena pertimbangan hubungan dengan lawan bicara. Gajonbeob adalah kebalikan dari apjonbeob, yaitu meninggikan orang yang 
seharusnya tidak ditinggikan karena mempertimbangkan status lawan bicara.

Kim (2016) menyebutkan bahwa tingkat tutur pengisi fungsi subjek terwujud secara gramatikal dan pragmatik. Tingkat tutur untuk fungsi subjek langsung dan tidak langsung merupakan tingkat tutur yang masuk dalam kategori sintaksis, sedangkan apjonbeob dan gajonbeob masuk kategori pragmatik.

\section{2) Tingkat Tutur Bahasa Jawa}

Dalam bahasa Jawa, tingkat tutur disebut dengan istilah unda-usuk basa, yaitu penggunaan bahasa yang didasarkan pada perbedaan sikap santun pembicara terhadap lawan bicara (Poedjosoedarma, 1979). Tingkat tutur dalam bahasa Jawa dibagi berdasarkan kadar kesopanan. Ada tingkat tutur yang menunjukkan kadar kesopanan rendah, sedang dan tinggi. Tingkat tutur tersebut adalah ngoko, madya, dan krama.

Tingkat tutur ngoko merupakan tingkat tutur yang menunjukkan kadar kesopanan rendah dan menunjukkan tidak adanya rasa sungkan antara pembicara dengan lawan bicara. Ngoko biasa digunakan antar teman atau untuk menyatakan bahwa pembicara dan lawan bicara akrab. Selain itu, ngoko juga digunakan oleh orang yang lebih tua atau status sosialnya lebih tinggi kepada orang yang lebih muda atau status sosialnya lebih rendah.

Tingkat tutur madya adalah tingkat tutur yang mencerminkan kadar kesopanan sedang. Dalam tingkat tutur ini, rasa sungkan dan rasa hormat pembicara terhadap lawan bicara masih ada tetapi kadarnya tidaklah tinggi. Madya biasanya digunakan kepada orang yang status sosialnya lebih rendah dari pembicara, tetapi pembicara masih ingin menghormatinya.

Di antara tiga tingkat tutur yang ada dalam bahasa Jawa, tingkat tutur krama adalah tingkat tutur yang menunjukkan derajat kesopanan dan keseganan paling tinggi. Krama biasa digunakan kepada orang yang baru pertama kali ditemui, orang yang lebih tua atau status sosialnya lebih tinggi.

\section{3) Tingkat Tutur Pengisi Fungsi Subjek Langsung}

Tingkat tutur pengisi fungsi subjek langsung dalam bahasa Korea dapat diwujudkan melalui dua cara, yaitu gramatikal dan leksikal (Kim, 2016). Dalam bahasa Korea, subjek ditandai dengan $-i$ atau -ga. Apabila pengisi subjek ditinggikan, maka partikel yang dipakai bukan $-i$ atau -ga, tetapi -kkeseo. Namun, penghormatan pengisi fungsi subjek tidak hanya berhenti pada penggunaan partikel -kkeseo saja, tetapi pre-final ending -si- juga wajib dilekatkan pada predikat. Sebagai contohnya:

(1) 하나 교수님께서 오시죠?

$\begin{array}{ll}\text { Hana Gyosunimkkeseo } & \text { osijyo? } \\ \text { Hana Dosen } & \text { datang, kan? }\end{array}$

Berbeda dengan kalimat (1), dalam bahasa Korea pun sering digunakan kalimat yang tidak menggunakan penanda-kkeseo, tetapi 
menggunakan pre-final ending -si-. Hal tersebut dapat dilihat dari contoh berikut:

$$
\begin{array}{cc}
\text { 부장님이 } & \text { 부정적이시다. } \\
\text { Bujangnimi } & \text { bujeongjeokisida. }
\end{array}
$$

Kepala Departemen berprasangka negatif.

Pada kalimat (2) kata bujang mendapat akhiran -nim yang bermakna meninggikan posisi bujang, akan tetapi kata bujangnim sendiri tidak dilekati -kkeseo. Akan tetapi, pada predikatnya dilekati pre-final ending -si-. Berkaitan dengan hal ini, Han (2002) menyebutkan bahwa, untuk meninggikan subjek, tidak selalu ditandai penanda subjek -kkeseo. Subjek tetap ditinggikan meskipun hanya dengan memakai pre-final ending -si pada predikat kalimat. Akan tetapi, apabila -kkeseo dan pre final ending -si digunakan bersamaan maka kadar penghormatan untuk pengisi subjek lebih tinggi dibanding yang hanya memakai prefinal ending -si- saja.

Cara yang kedua untuk meninggikan pengisi subjek adalah dengan pemilihan kosakata. Kata-kata yang memiliki makna honorifik adalah gyesida yang berarti ada, phyeonchaneusida yang berarti sakit, malsseumhasida yang berarti berbicara, deusida atau jabsushida yang berarti makan, dan doragashida yang memiliki arti meninggal dunia. Jika kata-kata tersebut dipilih untuk digunakan, maka tidak perlu menambahkan pre final ending -si-.

Dalam tingkat tutur pengisi fungsi subjek langsung, selain ditinggikan, pengisi subjek juga bisa direndahkan. Koo
(2004) mengungkapkan bahwa perendahan orang lain (dishonorification) pada umumnya terwujud secara leksikal, yaitu menggunakan kata-kata yang memiliki makna merendahkan orang lain:

\section{(3) 너는 나랑 링에서 만나면 진짜 뒈져.}

Neoneun narang ringeseo mannamyeon jinjja dwejyeo

Kalau kau ketemu aku di ring, sungguh mampus kau.

Subjek pada kalimat (3), yaitu neo yang berarti kau direndahkan melalui penggunaan predikat dwejyeo. Sama halnya dengan kata jukta, dwejyeo ${ }^{4}$ juga berarti mati, tetapi bermakna merendahkan dan tidak pantas digunakan.

\section{(4) 너 술 처먹고 왔냐?}

\section{Neo sul cheomeokko watnya?}

Kau minum alkohol, lalu kemari?

Kata cheomeokta (kata dasar dari kata cheomeokko) berarti makan atau terkadang berarti minum dan merupakan kata yang

\footnotetext{
${ }^{4}$ Menurut Kim (2000: 210), dalam tingkat tutur yang terdiri atas tinggi dan rendah, kata dwejida yang merupakan kata dasar dwejyeo merupakan kata yang termasuk pada kategori rendah, yaitu kata yang tidak mengandung makna menghormati, tetapi bermakna merendahkan orang lain. Meskipun dwejida adalah kata yang kasar, tetapi dwejida pada dasarnya bukan makian. Dwejyeo bisa menjadi makian apabila pembicara menggunakannya dengan nada mengutuk (Lee, 2015: 74).
} 
maknanya lebih rendah dari pada meokta. Kata cheomeokta terwujud dari dua unsur, yaitu awalan cheo dan kata kerja meokta yang berarti makan. Awalan cheo- berasal dari kata chida yang berarti memukul. Menurut Koo (2004) gerakan memukul merupakan gerakan yang kasar dan menyerang. Makna dari gerakan ini kemudian berubah maknanya dari yang mencerminkan tingkah laku menjadi mencerminkan kualitas sesuatu. Gerakan yang kasar mencerminkan kualitas yang rendah dan kualitas yang rendah merupakan hal yang rendah. Selain cheo, ada beberapa awalan yang apabila dilekatkan pada kata kerja tertentu menambahkan makna rendah pada kata tersebut. Awalan tersebut antara lain adalah, Ja-, Deuri-, Ttaeryeo-, Ssa-, dan Heoteun-.

Sama halnya dengan bahasa Korea, dalam bahasa Jawa, subjek dalam kalimat juga ditinggikan atau direndahkan. Dalam meninggikan subjek, bahasa Jawa menggunakan kata-kata yang masuk dalam krama inggil. Contohnya dapat dilihat dalam kalimat berikut:

\section{(5) "Simbok seneng tenan Allah maringi rejeki" (....) \\ Ibu senang sekali Allah memberi re- jeki.}

Situasi pada kalimat di atas diucapkan oleh ibu kepada anaknya. Saat menyebutkan dirinya kepada anaknya, si ibu tidak memakai kata kerja yang bermakna meninggikan, tetapi untuk Allah, si ibu memakai kata maringi, bukan ngenehi yang merupa- kan kosa kata ngoko dari memberi. Hal ini dikarenakan Allah yang merupakan Tuhan, menduduki posisi tertinggi dari segalanya.

(6) wong tuwamu wis pirsa nek kowe mlayu saka rumah sakit?

Orang tuamu sudah tahu kalau kamu kabur dari rumah sakit?

Dalam kalimat (6) hampir secara keseluruhan memakai ngoko dan hanya satu saja yang memakai krama, yaitu pada kata pirsa yang bentuk ngokonya adalah ngerti yang berarti tahu. Kata pirsa memiliki hubungan dengan subjek, yaitu "orang tua". Orang tua adalah orang yang lebih tua dari pembicara atau pendengar dan orang yang patut dihormati, sehingga orang tua seharusnya dikenai honorifik. Oleh karena itu, kata pirsa dipilih untuk meninggikan subjek.

Bentuk tuturan seperti pada kalimat (5) dan (6) disebut dengan ragam ngoko alus dalam sistem tingkat tutur bahasa Jawa. Ngoko alus adalah penggunaan satu atau dua kata krama dalam kalimat yang sebagian besar memakai kosakata ngoko. Krama digunakan untuk menghormati orang kedua atau ketiga yang muncul dalam fungsi subjek. Kosakata krama yang muncul pada tingkat tutur langsung ini adalah terbatas pada kata kerja (Indrayanto dan Yulianti, 2018).

Orang yang mengisi fungsi subjek tidak hanya ditinggikan tetapi juga direndahkan. Cara perendahan dilakukan dengan menggunakan kata-kata yang mengandung 
makna merendahkan orang. Sebagai contohnya:

(7) "Wee, malah deknen minggat" (...)

(ekslamasi) malah dia pergi.

(8) "Modar kowe!"

Mampus kau!

Kata minggat dan modar masing-masing memiliki arti pergi (tanpa pamit) dan mati. Akan tetapi, kata-kata tersebut mengandung makna kasar dan merendahkan subjek. Selain kata minggat, ada beberapa kata lain seperti modar yang berarti mati, nguntal yang berarti makan, micek yang berarti tidur dan sebagainya (Wijana, 2008).

\section{4) Tingkat Tutur Pengisi Fungsi Subjek Tidak Langsung}

Tingkat tutur untuk fungsi subjek tidak langsung bahasa Korea dapat dilihat melalui contoh berikut:

$\begin{array}{lll}\text { (9) 과장님 } & \text { 애들이 } & \text { 셋이나 } \\ \text { 되시잖아요. } & & \\ \text { Gwajangnim } & \text { aedeuri } & \text { sesina } \\ \text { dwesijanhayo. } & & \end{array}$

Kepala Bagian anak-anaknya ada tiga.

Pengisi fungsi subjek pada kalimat (9) adalah gwajangnim aedeul atau anakanak gwajangnim atau Kepala Bagian. Pengisi subjek tersebut adalah orang yang memiliki hubungan dengan objek honorifik. Oleh karena itu, pada predikatnya, yaitu $d w e$ - dilekati pre-final ending -si- yang merupakan pre-final ending honorifik.
Dengan begitu, dalam kalimat tersebut yang ditinggikan bukanlah si anak-anak, tetapi si Kepala Bagian. Dengan kata lain, Kepala Bagian ditinggikan melalui si anakanak sebagai pengisi fungsi subjek dengan melekatkan pre-final ending pada predikat. Jika dalam tingkat tutur pengisi fungsi subjek langsung terdapat dua kategori, yaitu tinggi dan rendah, maka dalam tingkat tutur pengisi fungsi subjek tidak langsung hanya terdapat tinggi saja. Hal ini dikarenakan tingkat tutur pengisi fungsi subjek tidak langsung merupakan perluasan dari tingkat tutur pengisi fungsi subjek langsung (Kim, 2016: 266).

Tingkat tutur pengisi fungsi subjek yang tidak langsung dalam bahasa Jawa dapat dilihat melalui contoh berikut:

\section{Kok penggalihe kadosipun susah?}

Kenapa perasaannya sepertinya susah?

Pada kalimat (11), subjek ditempati oleh kata penggalih yang berarti perasaan. Namun, kata 'perasaan' ini memakai bentuk krama inggil, sehingga memiliki makna meninggikan. Akan tetapi, dalam kalimat (11) bukan perasaan itu sendiri yang ditinggikan, tetapi yang orang yang memiliki perasaan tersebut.

(12) Priyayine manis tur luwes.

Orangnya manis dan anggun.

Sama halnya dengan kalimat (11), subjek pada kalimat (12) ditempati oleh kata priyayi yang merupakan bentuk krama dari 
wong yang berarti orang. Akan tetapi, kata priyayi pada konteks kalimat (12) artinya lebih merujuk pada sifat atau watak. Pada kalimat tersebut, yang menjadi target honorifik bukanlah "watak" itu sendiri tetapi orang yang memiliki watak tersebut. Ragam seperti kalimat (11) dan (12) dalam bahasa Jawa dikenal dengan ragam ngoko alus, sama seperti ragam pada tingkat tutur langsung untuk fungsi subjek bahasa Jawa. Jika dalam tingkat tutur langsung penggunaan kosakata krama terbatas pada kata kerja, maka pada tingkat tutur tidak langsung kosakata krama terbatas pada kata benda atau kata ganti orang (Indrayanto dan Yulianti, 2015: 38).

Berbeda dengan bahasa Korea, dalam tingkat tutur pengisi fungsi subjek yang tidak langsung dalam bahasa Jawa dikenal konsep merendahkan pengisi fungsi subjek dalam kalimat.

Contoh dapat dilihat sebagai berikut:

(13) Pa cangkeme ra ledhes ${ }^{5}$ ? Apa mulutnya tidak luka?

(14) Rupamu kaya jangan bobor!

Mukamu seperti sayur bobor!

Pada kalimat (13) dan (14), subjek ditempati oleh kata cangkeme dan rupamu. Kata cangkem memiliki arti mulut, tetapi kata cangkem bermakna kasar dan merendahkan seseorang. Kata cangkem merupakan bentuk figuratif untuk menyatakan celaan ter-

\footnotetext{
${ }^{5}$ Ledhes adalah luka pada kedua sudut mulut.
}

hadap seseorang (Wijana: 2008). Kata rupa sendiri berarti muka yang maknanya kasar. Biasanya digunakan untuk mengungkapkan kekesalan terhadap seseorang. Pada kalimat (13) dan (14), kata cangkem dan rupa digunakan untuk merendahkan pemiliknya.

\section{5) Apjonbeob (압존법)}

Apjonbeob adalah tidak meninggikan objek yang seharusnya ditinggikan di depan lawan bicara yang statusnya lebih tinggi dari pembicara dan objek (Lee, 2016). Apjonbeob dalam bahasa Korea dapat dilihat pada contoh kalimat berikut:

할아버지, 아버지가 왔어요. ${ }^{6}$

Harabeoji, abeojiga wasseoyo.

Kakek, Ayah sudah datang.

Pembicara pada kalimat di atas adalah cucu, pendengarnya adalah kakek, dan pengisi fungsi subjek adalah ayah. Bagi si cucu, ayah adalah objek honorifik, tetapi tidak dikenai honorifik. Hal ini dikarenakan si cucu mempertimbangkan hubungan pendengar yang posisinya lebih tinggi dari ayahnya, yaitu kakek dengan ayah.

Menurut Lee (2016), pemerintah Korea melalui lembaga National Institute of Korean Language tidak memperbolehkan penggunaan apjonbeob di masyarakat atau di perusahaan mulai tahun 1992. Ketentuan ini tertuang pada

\footnotetext{
${ }^{6}$ Contoh diambil dari paparan Lee dalam jurnal The Change of Korean Honorific Category's Nature and "Apjonbeob" (2016).
} 
Pyojun Hwabeob Haeseol (표준 화법 해설) atau Panduan Berbahasa Korea Standar ${ }^{7}$, yang berbunyi:

“윗사람에 관해서 말할 때는 듣는
사람이 누구이든지 '-시-'를 넣어
말하는 것이 원칙이다. 즉 '[평사원이]
사장님, 이 과장님 어디 가셨습
니까?'하고 말한다." (National
Institute of Korean Language, 1992:
97 )
"Sudah menjadi aturan bahwa
harus tetap menggunakan -si-
ketika berbicara dengan orang
yang lebih tinggi statusnya,
siapapun ia. Oleh karena itu,
perkataan yang benar adalah
'Pegawai: "Direktur, Kepala

Bagian Lee pergi kemana? ${ }^{8, "}$.

Ketentuan tersebut masih berlaku dalam Etika Berbahasa Korea Standar atau Pyojun Eoneo Yejeol (표준 언어 예절). Etika Berbahasa Korea Standar ini merupakan revisi dari Panduan Berbahasa Korea

7 Panduan Berbahasa Korea Standar adalah publikasi yang isinya mengatur tentang penggunaan panggilan, sapaan, ucapan salam, dan tingkat tutur bahasa Korea dalam kehidupan sehari-hari.

8 Secara teori, pengisi fungsi subjek diisi oleh Kepala Bagian Lee seharusnya tidak perlu ditinggikan dengan memberi pre-final ending -sipada predikat kalimat karena lawan bicara adalah orang yang lebih tinggi, yaitu direktur. Akan tetapi, menurut ketentuan, Kepala Bagian Lee harus ditinggikan meskipun lawan bicara statusnya lebih tinggi.
Standar yang dikeluarkan pada tahun 2011. Ketentuan terkait penggunaan apjonbeob dapat dilihat di bawah ini:

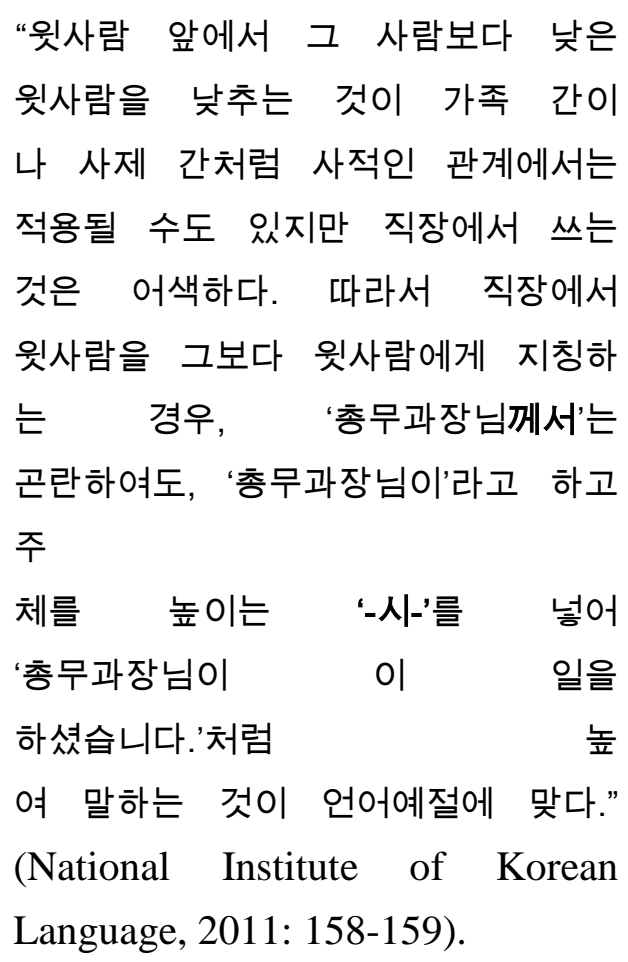

Arti dari ketentuan di atas adalah tidak meninggikan orang yang berstatus lebih tinggi dari pembicara tetapi lebih rendah dari lawan bicara bisa diterapkan pada hubungan pribadi, seperti hubungan guru-murid atau keluarga, tetapi jika digunakan di lingkungan kerja, maka menjadi tidak natural atau canggung. Oleh karena itu, ketika merujuk orang yang statusnya lebih tinggi di lingkungan kerja di depan orang yang statusnya paling tinggi, meninggikan orang tersebut adalah hal yang sesuai dengan etika berbahasa. Hal ini dapat dilihat pada contoh seperti tidak menggunakan penanda subjek honorifik -kkeseo pada 'Kepala Divisi Umum' sebagai pengisi fungsi subjek dan menggunakan pre-final ending -si- pada 
predikat untuk meninggikan si 'Kepala Divisi Umum.'

Meskipun demikian, penggunaan apjonbeob masih diperbolehkan dalam lingkungan keluarga. Tidak meninggikan orang tua di depan kakek atau nenek merupakan tradisi dan etika. Meskipun demikian, tradisi sudah berubah dan meninggikan orang tua di depan orang yang statusnya lebih tinggi pun sudah umum. Oleh karena itu, hal seperti ini diperbolehkan (National Institute of Korean Language, 1992: 95), (National Institute of Korean Language, 2011: 154).

Secara teoretis, apjonbeob disebutkan di beberapa buku yang membahas tingkat tutur bahasa Korea. Akan tetapi, dari sumber data yang digunakan oleh peneliti, tidak ditemukan satu pun kalimat yang menunjukkan penggunaan apjonbeob. Kemungkinan tidak ditemukannya data tentang apjonbeob adalah ada kaitannya dengan Etika Berbahasa Korea Standar. Drama Misaeng yang tayang pada tahun 2014 bercerita tentang kehidupan kerja di perusahaan, sedangkan Etika Berbahasa Korea Standar keluar pada tahun 2011 dan tidak memperbolehkan penggunaan apjonbeob di lingkungan perusahaan. Drama Fight for My Way tayang setelah Etika Berbahasa Korea Standar 2011, yaitu 2017. Drama ini bercerita tentang persahabatan dan cerita yang berkaitan dengan keluarga terbatas pada keluarga inti saja, sedangkan menurut Etika Berbahasa Korea Standar, apjonbeob dapat digunakan di lingkungan keluarga besar yang melibatkan orang tua, kakek-nenek atau paman-bibi dan sebagainya.

Apjonbeob dalam bahasa Jawa dapat dilihat pada contoh berikut:

(16) "Nyuwun ngapunten mas, kanca kula boten sengaja."

Mohon maaf mas, teman saya tidak sengaja.

Kalimat di atas diucapkan oleh seorang siswa SMA yang temannya tidak sengaja badannya menabrak seseorang yang asing. Pada kalimat (16) seluruh kalimat adalah krama kecuali kata kanca. Kata kanca menjadi rencang pada tingkat krama, tetapi karena mempertimbangkan pendengar yang merupakan orang yang lebih tua dari subjek, maka pembicara memilih kata kanca yang tingkatnya rendah untuk meninggikan pendengar.

(17) "Nyuwun pangapunten, Pak, (Yem) tasih anyaran, dereng dangu ndherek mriki."

Mohon maaf, Pak, (Yem) masih baru, belum lama ikut di sini.

Pembicara pada kalimat (17) adalah pemilik rumah, pendengar adalah polisi, dan subjek adalah Yem yang merupakan pembantu dari pemilik rumah. Pada kalimat di atas, hampir keseluruhan kalimat memakai krama kecuali kata anyaran yang berarti baru. Seharusnya pembicara menggunakan bahasa krama dari anyaran untuk merujuk Yem, mengingat pendengar dan Yem tidaklah saling mengenal. Akan tetapi, pem- 
bicara memilih memakai kata anyaran karena status pendengar. Pekerjaan pendengar adalah polisi dan polisi memiliki status sosial lebih tinggi dari pembantu.

\section{6) Gajonbeob (가존법)}

Gajonbeob dalam bahasa Korea dapat dilihat dalam contoh berikut:

(18) "다음 주 월요일에 임형재 선생님을 찾아뵈면 될 것 같습니다.”

Daeum ju woryoire Imhyeongjae seonsaengnim chajabwemyeon dwel geot gatseumnida.

Hari senin minggu depan, Anda tinggal menyambangi Pak Im Hyeong Jae.

Kalimat di atas diucapkan oleh seorang dosen (pembicara) kepada mahasiswanya (pendengar) untuk menyambangi dosen lain yang bernama Im hyeong Jae. Dosen yang akan disambangi oleh pendengar bukanlah target honorifik dari sudut pandang pembicara. Akan tetapi, dikarenakan mempertimbangkan dari sudut pandang pendengar, maka dosen tersebut adalah target honorifik. Oleh karena itu, pembicara memakai kata chajabwebta yang merupakan honorifik dari kata chajaboda.

Gajonbeob dalam bahasa Jawa dapat dilihat dalam contoh berikut:

(19) “Apa ibumu karo ramamu ora ngajari krama?

Apa ibumu dan ayahmu tidak mengajarimu krama?
Kalimat di atas diucapkan oleh kakek kepada cucunya. Sang kakek memakai kata rama untuk merujuk ayah dari cucunya. Rama merupakan bentuk krama dari bapak (Robson, 1987: 514). Ayah si cucu yang merupakan anak dari si kakek seharusnya tidak perlu dikenai honorifik oleh si kakek. Akan tetapi, karena kakek mempertimbangkan dari posisi si cucu, maka si kakek memakai krama untuk menyebut ayah.

Kalimat (19), dalam bahasa Jawa dikenal dengan konsep mbasakake yang berarti 'membahasakan'. Konsep mbasakake digunakan untuk mengajarkan lawan bicara yang usianya lebih muda atau status sosialnya lebih rendah untuk meninggikan orang lain yang muncul dalam kalimat.

\section{7) Persamaan Tingkat Tutur untuk Fungsi Subjek Bahasa Jawa dan Bahasa Korea}

Meskipun bahasa Korea dan bahasa Jawa memiliki sistem tingkat tutur yang berbeda, bahasa Jawa juga memiliki konsep tingkat tutur seperti bahasa Korea. Rahayuning (2018) menyebutkan bahwa tingkat tutur bahasa Jawa mirip dengan tingkat tutur lawan bicara bahasa Korea. Selain itu, dari analisis yang telah dilakukan, bahasa Jawa juga memiliki konsep tingkat tutur pengisi fungsi subjek seperti bahasa Korea.

Pada tingkat tutur pengisi fungsi subjek langsung, sama halnya dengan bahasa Korea, bahasa Jawa juga mengenal kategori tinggi dan rendah. Untuk meninggikan pengisi fungsi subjek, bahasa Jawa dan bahasa Korea menggunakan kosakata yang mengandung makna honorifik pada 
predikat. Bahasa Korea menggunakan katakata seperti gyesida yang berarti ada, phyeonchaneusida yang berarti sakit, malsseumhasida yang berarti berbicara, deusida atau jabsushida yang berarti makan, dan doragashida. Bahasa Jawa menggunakan kata-kata krama.

Pada tingkat tutur fungsi subjek kategori rendah, bahasa Jawa dan bahasa Korea sama-sama menggunakan kosakata untuk merendahkan pengisi fungsi subjek. Dalam bahasa Korea, sesuatu yang kecil, kotor, tidak berguna, tidak menunjukkan kedewasaan, tidak bernyawa, kasar atau tidak rapi, dan ganjil adalah sesuatu yang rendah. Kata-kata yang mengandung makna tersebut adalah kata-kata rendah (Koo, 2004). Dalam bahasa Jawa, kata-kata yang dipakai biasanya merujuk pada aktivitas manusia berupa makan, minum, tidur, berbicara, tidur dan pergi yang dilakukan tidak sesuai lazimnya dan kata-kata yang merujuk pada binatang, benda, dan kondisi fisik manusia yang tidak menyenangkan (Wijana, 2008).

Pada tingkat tutur pengisi fungsi subjek tidak langsung, bahasa Jawa samasama memiliki konsep meninggikan. Bahasa Korea meninggikan objek tingkat tutur dengan melekatkan pre-final ending -si-, sedangkan bahasa Jawa menggunakan kosa kata krama. Dari sumber data yang telah dikumpulkan, tidak ditemukan data yang berkaitan dengan apjonbeob. Oleh karena itu, tidak dapat diidentifikasi secara detail apa saja persamaan yang dimiliki di kedua bahasa tentang apjonbeob. Akan tetapi, pada gajonbeob, keduanya sampai saat ini masih digunakan secara luas di kalangan masyarakat.

\section{8) Perbedaan Tingkat Tutur untuk Fungsi Subjek Bahasa Jawa dan Ba- hasa Korea}

Pada tingkat tutur pengisi fungsi subjek langsung, bahasa Korea meninggikan subjek secara gramatikal. Bahasa Korea menggunakan penanda subjek honorifik -kkeseo dan pre-final ending -si- pada predikat kalimat yang keduanya digunakan secara bersamaan. Akan tetapi, bahasa Jawa meninggikan subjek secara leksikal dengan menggunakan kosakata bentuk krama. Pada situasi tertentu, hal ini digolongkan menjadi bentuk tingkat tutur ngoko alus. Situasi tersebut adalah ketika keseluruhan kalimat memakai ragam ngoko, tetapi untuk merujuk orang yang menempati fungsi subjek, pembicara memakai bentuk krama. Selain itu, meskipun bahasa Korea dan bahasa Jawa sama-sama memakai kosakata yang mengandung makna honorifik untuk meninggikan pengisi fungsi subjek, tetapi jumlah kosakata bahasa Korea terbatas, sedangkan bahasa Jawa tidak terbatas. Dalam tingkat tutur pengisi fungsi subjek langsung kategori rendah, bahasa Jawa dan bahasa Korea sama-sama menggunakan kosakata yang memiliki makna merendahkan. Kosakata bahasa Korea yang bermakna merendahkan sebagian besar terbentuk dari proses leksikalisasi, sedangkan bahasa Jawa tidak. Pada tingkat tutur pengisi fungsi subjek tidak langsung, bahasa Korea hanya mempunyai tingkat tutur pengisi subjek 
tidak langsung kategori tinggi saja, tetapi bahasa Jawa mempunyai tinggi dan rendah. Dalam bahasa Korea, meninggikan pengisi fungsi subjek secara tidak langsung terwujud secara gramatikal, yaitu menggunakan pre-final ending -si- pada bentuk dasar dari predikat kalimat. Bahasa Jawa tidak memakai penanda gramatikal, tetapi menggunakan kosakata yang mengandung makna honorifik, yaitu umumnya kosakata bentuk krama. Jika dalam bahasa Korea, honorifik diwujudkan melalui predikat, maka dalam bahasa Jawa honorifik dikenakan langsung pada pengisi fungsi subjek. Dalam situasi tertentu, bentuk tingkat tutur tidak langsung ini dalam bahasa Jawa disebut dengan ngoko alus. Pada kategori rendah, bahasa Jawa menggunakan kosakata yang bermakna merendahkan. Kosakata tersebut langsung digunakan pada pengisi fungsi subjek.

Pada apjonbeob, tidak ditemukan data terkait apjonbeob dalam bahasa Korea, sedangkan dalam bahasa Jawa ditemukan. Terkait dengan apjonbeob, pemerintah Korea melalui National Institute of Korean Language mengatur tentang penggunaan apjonbeob. Aturan tersebut tertuang pada Panduan Berbahasa Korea Standar yang terbit pada tahun 1992 dan aturan tersebut tetap berlaku dalam versi pembaruannya, yaitu Etika Berbahasa Korea Standar yang dikeluarkan pada tahun 2011. Dalam dua publikasi tersebut, apjonbeob hanya diperbolehkan digunakan dalam lingkungan keluarga saja dan penggunaan di dunia kerja atau perusahaan dan masyarakat tidak diperbolehkan. Hal ini berpengaruh pada tidak dimuatnya lagi hal-hal yang berkaitan dengan apjonbeob di buku ajar bahasa Korea di sekolahsekolah (Lee, 2016).

Berbeda dengan bahasa Korea, bahasa Jawa juga mengenal konsep apjonbeob. Apjonbeob masih digunakan hingga saat ini dan tidak ada aturan dari pemerintah tentang pembatasan bentuk tingkat tutur tertentu. Hal ini dikarenakan status antara pembicara dan mitra tutur masih dianggap penting dalam masyarakat Jawa. Apabila konsep seperti apjonbeob tidak diterapkan dalam kehidupan seharihari, maka pembicara akan dianggap sebagai orang yang ora reti unggah-ungguh atau tidak tahu tata krama.

Gajonbeob dalam bahasa Korea dan bahasa Jawa hingga saat ini masih digunakan secara luas. Dalam bahasa Jawa, konsep seperti ini sering disebut dengan istilah mbasakake yang berarti membahasakan. Sedangkan bahasa Korea tidak memiliki istilah tersebut atau istilah lain.

\section{KESIMPULAN}

Dari analisis yang telah dilakukan terhadap tingkat tutur untuk fungsi subjek bahasa Korea dan bahasa Jawa dapat ditarik kesimpulan sebagai berikut. Pertama, bahasa Jawa memiliki konsep tingkat tutur untuk fungsi subjek seperti halnya bahasa Korea. Kedua, tingkat tutur pengisi fungsi subjek terwujud secara gramatikal, sedangkan bahasa Jawa terwujud secara leksikal. Ketiga, tingkat tutur langsung dan tidak langsung dalam bahasa Jawa merupakan ragam ngoko alus pada situasi ter- 
tentu. Situasi tersebut adalah apabila keseluruhan kalimat berbentuk ngoko, kecuali satu atau dua kata krama yang merujuk pada subjek. Keempat, pemerintah Korea mengeluarkan ketentuan tentang penggunaan salah satu jenis tingkat tutur pengisi fungsi subjek, yaitu apjonbeob. Apjonbeob tidak diperbolehkan digunakan di dunia kerja atau masyarakat, tetapi di lingkup keluarga boleh. Ketentuan tersebut tertuang pada Etika Berbahasa Korea Standar yang dikeluarkan pada tahun 2011. Namun, hal demikian tidak ada dalam bahasa Jawa. Kelima, dalam bahasa Korea, meninggikan seseorang yang seharusnya tidak perlu ditinggikan disebut sebagai $g a$ jonbeob, sedangkan dalam bahasa Jawa konsep seperti ini dikenal dengan istilah mbasakake.

\section{DAFTAR PUSTAKA}

Abidan, A. (2011). Bantul Sangsaya Pinunjul. Balai Bahasa.

Brown, P., Levinson, S.C. (1996). Politeness, Some Universals in Language Usage. Cambridge University Press.

Digital Learning Project. (2014). Sri Ngilang - "The Disappearance of Sri" A play in Javanese. Diakses pada 3 Agustus 2019, 20:43 WIB dari https://www.youtube.com/watch?v=u $\underline{\text { TL6BMG8JZ0\&t=1039s }}$

Han, G. (2002). A Study of the Honorifics of Contemporary Korean. Youngrak.

Indrayanto, B., Yuliastuti, K. (2015). Fenomena Tingkat Tutur dalam Bahasa Jawa Akibat Tingkat Sosial Masyarakat. Magistra, 91, 37-44.
Kim, U. S. (2000). A Historical Study of Lexical Honorifications in Korean. Korean Linguistic, 11, 185-212. . (2016). Language and Its Components. Seoul: Hankuk Munhwasa.

Koo, H. J. (2004). A Cognitive Analysis of Lexicalization Patterns of (Dis-) Honorification in Korean. Korean Semantics, 14, 97-120.

Lee, J. T. (2016). Linguistic Norms about Korean Apjonbeop and Linguistic Reality. Inmunnonchong, 30, 37-47. (2016). The Change of Korean Honorific Category's Nature and “Apjonbeob”. Munbeob Gyoyuk, 28, 165-181.

Lee, S. Y. (2015). A Study on the Concept of Slang, Vulgar Words, and Swearing in Korean. The Journal of Language \& Literature, 64, 59-80.

Lee, Y.H. (2001). A Study on Politeness in Contemporary Korean. Yeonrak Publisher.

National Institute of Korean Language. (1992). South Korean Standard Speech Handbook (Pyojun Hwabeob Haeseol). National Institute of Korean Language.

National Institute of Korean Language. (2011). Standard Linguistic Manners (Pyojun Eoneo Yejeol). National Institute of Korean Language.

Poedjasoedarma, S. (1979). Tingkat Tutur Bahasa Jawa. Departemen Pendidikan dan Kebudayaan.

Rahayuning, W. N. (2018). A Contrastive Study of Korean and Javanese Rela- 
tive Honorific. Unpublished thesis. Kyunghee University.

Robson, S.O. (1987). The Terminology of Javanese Kinship. Journal of the Humanities and Social Sciences of Southeast Asia and Oceania 143, 507-518.
Wahyudi, A. S. (2014). Mak Ana Asu Mlebu Ngomah. Garudhawaca.

Wijana, I. D. P. (2008). Kata-Kata Kasar dalam Bahasa Jawa. Humaniora, 3, 249-256. 